\title{
Pendidikan Karakter Pada Anak Sekolah Dasar di Era Digital
}

\author{
Dini Palupi Putri \\ Institut Agama Islam Negeri (IAIN) Curup \\ dinigusnadi@gmail.com
}

\begin{abstract}
Character education is an application process of etiquette value and religious into the students through knowledge, the application of the values to yourself, family and each friends into the teacher, environment and also into God Almighty. The social development of the child in the age of the elementary school have increase. From the first only socialize with the family in the house and then grow up to know another people around him. The child in this age also know the digital style either in the house, friends, school and the environment. In the digital era it's not only positive impact but also negative impact. In this case the figure of the parents, teacher and society are working to guide and watch the child to become good, excellent and have the positive aim to their self.
\end{abstract}

Keywords: Character Education, Primary School Children, Digital Era

\begin{abstract}
Abstrak : Pendidikan karakter adalah suatu proses penerapan nilai-nlai moral dan agama pada peserta didik melalui ilmu-ilmu pengetahuan, penerapan nilai-nilai tersebut baik terhadap diri sendiri, keluarga, sesama teman, terhadap pendidik dan lingkungan sekitar maupun Tuhan Yang Maha Esa. Perkembangan sosial anak usia sekolah dasar sudah bertambah, dari yang awalnya hanya bersosial dengan keluaga di rumah, kemudian berangsur-angsur mengenal orang-orang disekitarnya. Anak pada usia ini juga telah mengenal gaya hidup digital, baik itu dari rumah, teman-teman, sekolah dan lingkungan sekitar. Era digital tidak hanya punya dampak positif, tapi juga berdampak negatif, disinilah peran kita sebagai orang tua, pendidik dan masyarakat dewasa membimbing dan mengawasi anak untuk menjalaninya dengan baik, tepat, dan bermanfaat positif bagi anak itu sendiri.
\end{abstract}

Kata kunci: Pendidikan Karakter, Anak Sekolah Dasar, Era Digital

\section{PENDAHULUAN}

Pendidikan adalah proses perubahan tingkah laku, penambahan ilmu pengetahuan dan pengalaman hidup agar peserta didik menjadi lebih dewasa

AR-RIAYAH : Jurnal Pendidikan Dasar vol. 2, no. 1, 2018

STAIN Curup - Bengkulu| p ISSN 2580-362X; e ISSN 2580-3611

http://journal.staincurup.ac.id/index.php/JPD 
dalam pemikiran dan sikap. Pendidikan di era digital saat ini sangatlah pesat, kemajuan dalam bidang teknologi tidak hanya dinikmati oleh orang dewasa saja, anak-anak usia sekolah dasar juga sudah bisa menikmati dari hasil perkembangan teknologi saat ini. Teknologi banyak dimanfaatkan dalam dunia pendidikan, sebagai sarana dan prasarana interaksi antara pendidik dan peserta didik. Perkembangan teknologi saat ini mempunyai dampak positif dan damapak negatif, sebaiknya dampak positif lebih dominan dimanfaatkan oleh pengguna teknologi.

Munculnya banyak kasus yang destruktif dalam konteks kebangsaan, misalnya terjadinya sentimen antar etnis, perselisihan antar suku, kasus-kasus narkoba, tawuran antar pelajar, kekerasan terhadap anak, begal di mana-mana, kasus Bullying, menunjukkan karakter kebangsaan yang lemah. Pembentukan karakter sedari dini akan menumbuhkan budaya karakter bangsa yang baik dan kunci utama dalam membangun bangsa.

Pendidikan karakter bertujuan agar peserta didik sebagai penerus bangsa mempunyai akhak dan moral yang baik, untuk menciptakan kehiupan berbangsan yang adil, aman dan makmur. Tujuan Pendidikan dalam UndangUndang Nomor 20 tahun 2003 tentang Sistem Pendidikan Nasional yang menyebutkan bahwa "Pendidikan nasional berfungsi mengembangkan kemampuan dan membentuk watak serta peradaban bangsa yang bermartabat dalam rangka mencerdaskan kehidupan bangsa, bertujuan untuk berkembangnya potensi peserta didik agar menjadi manusia yang beriman dan bertaqwa kepada Tuhan Yang Maha Esa, berakhlak mulia, sehat, berilmu, cakap, kreatif, mandiri dan menjadi warga negara yang demokratis serta bertanggung jawab"1

Landasan pendidikan karakter disebut di dalam Alqur'an Q.S 31:17 "Hai anakku, dirikanlah sholat dan suruhlah manusia mengerjakan yang baik dan cegahlah mereka dari perbuatan yang mungkar dan bersabarlah terhadap apa yang menimpa kamu. Sesungguhnya yang demikian itu termasuk hal-hal yang diwajibkan oleh Allah". 2 Al-qur'an menjelaskan dengan tegas agar manusia menyerukan dan menegakkan kebenaran dan menjauhkan perbuatan yang munkar. Pendidikan karakter yang diberikan seorang ayah kepada anaknya untuk selalu mengerjakan sholat, dan selalu bersabar.

${ }^{1}$ Departemen Pendidikan Nasional, Undang-Undang No 20 Tabun 2003, Jakarta: Depdiknas, 2003)

${ }^{2}$ Departemen Agama RI, Al-Qur'an dan Terjemahnya, (Jakarta:PT.Intermasa, 2000), 594 
Dewasa ini pemerintah memperkenalkan program pemerintah yang namanya Penguatan Pendidikan Karakter (PPK), PPK merupakan usaha untuk membudayakan pendidikan karakter di sekolah. Program PPK akan dilaksanakan dengan bertahap dan sesuai kebutuhan. Program PPK bertujuan untuk mendorong pendidikan berkualitas dan bermoral yang merata di seluruh bangsa. Penerbitan Peraturan Presiden nomor 87 pasal 2 tahun 2017 tentang Penguatan Pendidikan Karakter (PPK), PPK memiliki tujuan :

1. Membangun dan membekali peserta didik sebagai generasi emas Indonesia tahun 2045 dengan jiwa pancasila dan pendidikan karakter yang baik guna menghadapi dinamika perubahan di masa depan.

2. Mengembangkan platform pendidikan nasional yang meletakkan pendidikan karakter sebagai jiwa utama dalam penyelenggaraan pendidikan bagi peserta didik dengan dukungan pelibatan publik yang dilakukan melalui pendidikan jalur formal, nonformal, dan informal dengan memperhatikan keberagaman budaya indonesia dan

3. Merevitalisasi dan memperkuat potensi dan kompetensi penidik, tenaga kependidikan, peserta didik, masyarakat, dan lingkungan keluarga dalam mengimplementasikan PPK. ${ }^{3}$

Menurut Piaget anak usia 7 - 11 tahun mengalami tingkat perkembangan Operasinal konkret. Tingkat ini merupakan permulaan berpikir rasional. Ini berarti anak memiliki operasi-operasi logis yang dapat diterapkannya pada masalah-masala yang konkret. Bila mengadapi suatu pertentangan antara pikiran dan persepsi, anak dalam periode ini memilih mengambil keputusan logis dan bukan keputusan perseptual seperti anak praoperasional. Pada zaman digital, anak usia sekolah dasar sudah bisa mengoperasikan barang-barang teknologi seperti Ponsel, komputer, video game dan lain-lain.

Anak-anak dewasa ini lebih banyak menghabiskan waktu bermain games online, berinteraksi dengan media gadget, seperti telepon seluler, laptop dan Video Games. Aktivitas yang bersentuhan dengan teknologi lebih mewarnai kehidupan anak, daripada berinteraksi dengan teman sebaya di lingkungan

3 Peraturan Presiden No 87 Pasal 2 Tahun 2017, Penguatan Pendidikan Karakter, (http://www.setkab.go.id/wp-content/upload/2017/09/Perpres No 87 tahun 2017, (Diakses 20 april 2017) 
rumah, bermain sepak bola, bersepeda dan aktivitas bermain lainnya. ${ }^{4}$ Aktivitas anak usia sekolah dasar harus diawasi oleh keluarga, pendidik maupun masyarakat sekitar, agar anak tidak terkena dampak negatif dari teknologi digital.

Pendidikan karakter adalah segala sesuatu yang dilakukan guru, yang mampu mempengaruhi karakter peserta didik. Guru membantu membentuk watak peserta didik. Pendidikan karakter menanamkan kebiasaan tentang hal mana yang baik sehingga peserta didik menjadi paham tenang mana yang benar dan salah, mampu merasakan nilai yang baik dan biasa melakukannya. Pada periode anak sekolah dasar, metode yang dilakukan guru untuk mengembangkan karakter adalah pengarahan, pembiasaan, keteladanan, penguatan, hukuman. Nilai-nilai karakter yang bisa digali dalam pembelajaran seperti Religius, jujur, kerja keras, disiplin, rasa tanggung jawab, cinta tanah air, peduli terhadap lingkungan sekitar, jiwa sosial yang kuat.

Teknologi membantu memudahkan segala aktifitas manusia, pencarian informasi, penyampaian informasi. Teknologi secara umum adalah sebuah proses yang meningkatkan nilai tambah, teknologi merupakan produk yang digunakan dan dihasilkan untuk memudahkan dan meningkatkan kinerja, struktur atau sistam di mana proses dan produk itu dikembangkan dan digunakan. ${ }^{5}$

Teknologi bermanfaat sangat besar dalam dunia pendidikan. Pencarian tentang literasi-literasi untuk penambahan ilmu pengetahuan dalam pembelajaran, bisa dimanfaatkan teknologi. Peserta didik bisa menulusuri google atau yahoo dan situs lainnya dalam mencari jurnal, makalah, dan buku elektronik. Meskipun demikian, bukan berarti pembelajaran tidak menggunakan buku paket yang tersedia, penggunaan literasi dari Google atau situs lainnya hanya bertujuan untuk menambah pengetahuan dan bahan dalam proses pembelajaran.

Teknologi tidak lepas dari dampak negatif, untuk itu sebagai pendidik harus mengawasi peserta didik dalam memanfaatkan teknologi. Keluarga sebagai orang terdekat peserta didik, juga berpartisipasi dalam mengawasi dan

4 Salman Hasibuan, Budaya Media dan Partisipasi Anak di Era digital, Proceeding of International Post-Graduate Conference.(Surabaya:Prodi S2 Komunikasi Universitas AIRLANGGA Surabaya, 2015), 831

${ }^{5}$ Yulia Palupi, Digital Parenting Sebagai Wahana Terapi untuk. Menyeimbangkan Dunia Digital dengan Dunia Nyata Bagi Anak, (Yogyakarta: Seminar Nasional Universitas PGRI, 2015), 47 
membimbing peserta didik dalam memanfaatkan teknologi. Keluarga juga berhak mengawasi si anak dalam bergaul dengan siapa di lingkungan sekitar.

\section{Konsep Dasar Pendidikan Karakter}

Istilah karakter dalam bahasa yunani dan latin, charassein yang artinya "mengukir corak yang tetap dan tidak terhapuskan" watak atau karakter merupakan perpaduan dari segala tabiat manusia yang bersifat tetap sehingga menjadi tanda khusus untuk membedakan orang yang satu dengan yang lain.

Konsep dasar pendidikan karakter tertuang dalam Permendikbud No 23 tentang Penumbuhan Budi Pekerti tahun 2015. Penumbuhan Budi Pekerti (PBP) bertujuan:

1. menjadikan sekolah sebagai taman belajar yang menyenangkan bagi siswa, guru, dan tenaga kependidikan,

2. menumbuhkembangkan kebiasaan yang baik sebagai bentuk pendidikan karakter sejak di keluarga, sekolah dan masyarakat,

3. menjadikan pendidikan sebagai gerakan yang melibatkan pemerintah, pemerintah daerah, masyarakat dan keluarga, dan/ atau

4. menumbuhkembangkan lingkungan dan budaya belajar yang serasi antara keluarga, sekolah, dan masyarakat. ${ }^{6}$

Karakter akan terbentuk bila aktivitas dilakukan berulang-ulang secara rutin hingga menjadi suatu kebiasaan, yang akhirnya tidak hanya menjadi suatu kebiasaan saja tetapi sudah menjadi suatu karakter. Pembentukan karakter tidak dapat dilepaskan dari life skill. Life skill sangat berkaitan dengan kemahiran, mempraktekkan/ berlatih kemampuan, fasilitas, dan kebijaksanaan. Proses pengembangan keterampilan dimulai dari sesuatu yang tidak disadari dan tidak kompeten, kemudian menjadi sesuatu yang disadari dan kompeten.

Penanaman karakter dengan cara menanamkan nilai-nilai universal untuk mencapai kematangan karakter melalui penanaman cinta kasih dalam keluarga. Rasa rendah diri dapat menyebabkan seseorang melakukan kekerasan terhadap dirinya sendiri dan keluarga. Pendidikan sekarang ini masih melahirkan generasi yang ahli dalam pengetahuan sains dan teknologi, hal ini bukan

\footnotetext{
${ }^{6}$ Peraturan Menteri Pendidikan dan Kebudayaan Republik Indonesia Nomor 23 Tahun 2015 Tentang Penumbuhan Budi Pekerti . Jakarta: Permendikbud.
} 
merupakan suatu prestasi, karena pendidikan seharusnya menghasilkan generasi dengan kepribadian yang unggul dan sekaligus mengasai ilmu pengetahuan.

Penanaman dan pengembangan pendidikan karakter di sekolah menjadi tanggung jawab bersama. Keluarga menjadi kiblat perjalanan dari dalam kandungan sampai tumbuh menjadi dewasa dan berlanjut di kemudian hari. Lingkungan sekolah saat ini memiliki peran sangat besar pembentukan karakter anak. Peran guru tidak hanya sekedar sebagai pendidik semata, tetapi juga sebagai pendidik karakter, moral dan budaya bagi siswanya.

\section{Prinsip Pendidikan Karakter}

Pendidikan karakter adalah segala sesuatu yang dilakukan guru, yang mampu mempengaruhi karakter peserta didik. Guru membantu membentuk watak peserta didik berdasarkan prinsip-prinsip pendidikan karakter. Berikut ini prinsip-prinsip yang digunakan dalam pengembangan pendidikan nilai atau karakter bangsa yaitu:

1. Nilai dapat diajarkan atau memperkuat nilai-nilai luhur budaya bangsa melalui olah pikir, olah rasa, olah karsa, olah qalbu, dan olah raga dihubungkan dengan objek yang dipelajari yang terintegrasi dengan materi pelajaran.

2. Proses perkembangan nilai-nilai/karakter bangsa dilakukan melalui setiap mata pelajaran dan dalam setiap kegiatan pembelajaran.

3. Proses pengembangan nilai-nilai karakter bangsa merupakan proses yang berkelanjutan sejak peserta didik masuk dalam satuan pendidikan

4. Diskusi tentang berbagai perumpamaan objek yang dipelajari untuk melakukan olah pikir, olah rasa, olah qolbu, dan olah raga untuk memenuhi tuntutan dan munculnya kesadarn diri sebagai hamba Allah, anggota masyarakat dan bangsa maupun warga negara, dan sebagai bagian dari lingkungan tempat hidupnya.

5. Program perkembangan dirinya melalui kegiatan-kegiatan rutin budaya sekolah, keteladanan, kegiatan spontan pada saat kejadian, pengkondisian dan pengintegrasian pendidikan nilai karakter dengan 
materi pelajaran, serta merujuk kepada pengembangan kompetensi dasar setiap mata pelajaran. ${ }^{7}$

Pendidikan karakter pada tingkatan institusi mengarah pada pembentukan budaya sekolah, yaitu nilai-nilai yang melandasi perilaku, tradisi, kebiasaan keseharian, dan simbol-simbol yang dipraktikkan oleh semua warga sekolah dan masyarakat sekitar sekolah. Budaya sekolah merupakan ciri khas, karakter atau watak, dan citra sekolah tersebut di mata masyarakat luas.

\section{Peran Pendidikan dalam Penanaman Karakter}

Era modern memacu para pendidik untuk menghasilkan anak-anak bangsa yang sanggup menempatkan diri di tengah deru perubahan yang cepat, pilihan-pilihan jamak dan hidup yang cepat serta penuh tekanan. Lebih dari itu, para pendidik berkewajiban moril untuk mendorong mereka menjadi orangorang yang hidupnya mampu menggali makna dan memiliki akar pada nilai-nilai yang luhur, gambar diri yang kokoh dan ambisi-ambisi yang bermanfaat bagi manusia lain selain diri sendiri. Pendidik harus menghasilkan peserta didik yang mandiri, artinya mampu memilih berdasarkan nilai-nilai, gambar diri yang kokoh dan ambisi yang tepat. Penanaman karakter dalam perannya dalam bidang pendidikan adalah sebagai berikut:

1. Pembinaan watak, (jujur, cerdas, peduli, tangguh) merupakan tugas utama pendidika.

2. Mengubah kebiasaan buruk tahap demi tahap yang pada akhirnya menjadi bak. Dapat mengubah kebiasaan senang tetapi jelek yang pada akhirnya menjadi benci tetapi menjadi baik.

3. Karakter merupakan sifat yang teranam di dalam jiwa dan dengan sifat itu seseorang secara spontan dapat dengan mudah memancarkan sikap, tindakan dan perbuatan.

4. Karakter adalah sifat yang terwujud dalam kemampuan daya dorong dari dalam kelar untuk menampilkan perilaku terpuji dan mengandung kebajikan. 8

7 Saiful Bahri, Implementasi Pendidikan Karakter dalam Mengatasi Krisis Moral di Sekolah, 2015, TA'ALLUM Vol 03. No 01, juni 2015

8 Daryanto, Darmiatun Suryatri. 2013.Implementasi Pendidikan Karakter di Sekolah. (Gava Media: Yogyakarta), 68 
Penanaman-penanaman nilai karakter tersebut dapat diimplementasikan dan dijadikan budaya sekolah. Proses yang efektif untuk membangun budaya sekolah adalah dengan melibatkan dan mengajak semua pihak atau pemangku kepentingan untuk bersama-sama memberikan komitmennya. Keyakinan utama dari pihak sekolah harus difokuskan pada usaha menyemaikan dan menanamkan keyakinan moral, nilai dan norma.

Banyak nilai yang dapat dan harus dibangun di sekolah, seperti nilai peduli dan kreatif, jujur, tanggung jawab, disiplin, sehat dan bersih, saling peduli antar sesama. Sekolah adalah laksana taman atau lahan yang subur tempat menyemaikan dan menanam benih-benih nilai tersebut. Untuk itu, kepala sekolah, para guru dan karyawan harus fokus pada usaha pengorganisasian yang mengarah pada harapan di atas.

\section{Pendidikan Karakter di Era Digital}

Pada era digital saat ini, jarang sekali terlihat anak-anak bermain dengan permainan tradisional. Permainan tradisional memupuk rasa persaudaraan dan keakraban, anak-anak jadi lebih kreatif dengan menggunakan permainan tradisonal. Anak-anak zaman ini banyak berintegrasi dengan teknologi, seperti gadget dan vidoe games. Kini, waktu yang dihabiskan anak-anak dengan media setiap hari lebih banyak. Waktu yang dihabiskan untuk menonton televisi 3 jam di hari sekolah dan 7.4 jam pada hari libur, waktu bermain internet rata-rata 2.1 jam. ${ }^{9}$ Adapun yang harus dilakukan orang tua terhadap anak dalam pengasuhan digital atau digital parenting adalah sebagai berikut:

a. Meningkatkan dan memperbarui wawasan tentang internet dan gadget. Orang tua tidak bisa mengawasi anak-anak apabila orang tua gagap teknologi.

b. Jika di rumah ada internet, posisikan di ruang keluarga dan siapa yang dapat melihat apa yang dilakukan anak dalam mengakses internet.

c. Membatasi waktu pada anak dalam menggunakan gadget dan internet.

d. Memberikan pemahaman dan kesadaran bersama akan dampak negative dari internet atau gadget.

\footnotetext{
${ }^{9}$ Salman Hasibuan, Budaya Media dan Partisipasi Anak di Era digital, Proceeding of International Post-Graduate Conference. (Surabaya:Prodi S2 Komunikasi Universitas AIRLANGGA Surabaya, 2015), 833
} 
e. Secara tegas melarang sesegera mungkin jika ada yang tidak pantas ditonton

f. Menjalin komunikasi yang terbuka dua arah dengan anak-anak. ${ }^{10}$

Anak-anak era digital telah banyak dimanjakan dengan teknologi yang serba canggih, seperti mencari bahan pembelajaran melalui situs Google, permainan tradisional sudah banyak ditinggalkan. Ciri-ciri Generasi Digital adalah sebagai berikut:

1. Generasi digital ramai-ramai membuat akun di media sosial untuk membuktikan kepada dunia bahwa mereka ada.

2. Generasi digital cenderung lebih terbuka, blak-blakan, dan berfikit lebih agresif.

3. Generasi digital cenderung ingin memperoleh kebebasan. Mereka tidak suka diatur dan dikekang. Mereka ingin memegang kontrol dan internet menawarkan kebebasan berekspresi.

4. Generasi digital selalu mengakses dengan Google, Yahoo, atau sits lainnya. Kemampuan belajar mereka jauh lebih cepat karena segala informasi ada di ujung jari mereka. ${ }^{11}$

Saat ini seluruh elemen bangsa harus berpartisipasi aktif untuk mengembangkan karakter yang baik bagi calon penerus bangsa, untuk mewariskan karakter demi menunjukkan identitas bangsa yang berkarakter. Seorang pendidik haruslah menjadi panutan dalam perbuatan dan perkataan, sehingga dari karakter pendidiklah, karakter peserta didik bisa berpengaruh ke arah yang lebih baik. Menerapkan pendidikan karakter melibatkan orang dewasa dilingkungan sekolah, dilingkungan rumah harus jadi panutan, biasakan atau budayakan pendidikan karakter, penguatan pendidikan karakter di lingkungan sekitar pemerintah.

Teknologi digital mempunyai dampak positif dan negatif, qita sebagai norang yan dewasa harus membimbing, mengarahkan dan mengawasi agar anak lebih dominan mengambil manfaat positif dari teknologi digital ini. Dampak positif teknologi digital

10 Yulia Palupi. Digital Parenting Sebagai Wahana Terapi untuk. Menyeimbangkan Dunia Digital dengan Dunia Nyata Bagi Anak. (Yogyakarta: Seminar Nasional Universitas PGRI Yogyakarta, 2015), 49

${ }^{11}$ Sukiman, dkk. (2016). Seri Pendidikan Orang Tua: Mendidik Anak di Era Digital. Jakarta: Kementerian Pendidikan dan Kebudayaan. 
1. sarana penyampaian informasi, informasi suatu kejadia secara cepat, tepat dan akurat

2. mempermudah akses terhadap informasi baru, memperoleh informasi kapanpun dan dimanapun.

3. Media sosial, mempertemukan individu dengan orang yang baru, mempertemukan individu dengan teman lama yang jarang sekali bertemu, saran berbisnis.

4. Membantu dalam mencari informasi bahan pelajaran bagi peserta didik.

5. Media hiburan, seperti games online

6. Mempermudah komunikasi

Adapun dampak negatif dari teknologi digital, sebagai berikut:

1. Anak bersifat Individual, berkurangnya tingkat pertemuan langsung atau interksi antar sesama manusia.

2. Temperamen, kebiasaan bersosialisasi dengan media sosial, maka anak akan beranggapan bahwa dunia luar adalah ancaman.

3. Berita tanpa tanggung jawab, berita Hoax, Bulying.

4. Rentannya kesehatan mata, terutama mengalami rabun jauh atau rabun dekat.

5. Tak bisa menikmati hidup. Ketika menghadiri sebuah acara pesta, kita malah asik berfoto, tanpa menimati acara pesta dan musik.

6. Radiasi alat hasil teknologi membahayakan kesehatan otak anak.

7. Maraknya kasus penipuan lewat sms, telepon dan internet.

8. Mudahnya mengakses video porno.

9. Anak lupa akan pekerjaan rumah yang ditugaskan oleh guru dan lupa melaksanakan ibadah, seperti sholat dan mengaji.

10. Anak menjadi sasaran kejahatan, seperti penculikan anak dan pemerkosaan anak.

Baru-baru ini banyak diberitakan tentang kasus bullying pada anak sekolah dasar. Dampak dari bullying, pelaku anak sekolah dasar bisa berlanjut pada saat ia melanjutkan sekolah pada tingkat berikutnya, pelaku bullying bisa melakukan kekerasan lagi pada tingkat sekolah berikutnya. Dampak bullying 
terhadap korban, ia akan memiliki harga diri yang rendah, minder dan tidak percaya diri, cenderung tidak berbaur dengan kawan-kawan sekolah. Dampak bullying terhadap teman-teman yang menyaksikan, mereka akan merasa terancam dan takut akan menjadi korban berikutnya.

Akses vidoe yang berbau pornografi sangat susah untuk dibatasi oleh pemerintah, betapa situs-situs porno mengakar dimana-mana dalam internet. Untuk itu harus ada pengawasan yang ketat kepada anak saat menggunakan ponsel. Sebaiknya anak usia sekolah dasar tidak usah diberi fasilitas seperti gadget agar anak fokus menjalani masa kanak-kanaknya dengan bersosialisasi dengan alam dan dunia luar.

Menerapkan pendidikan karakter pada era digital ini sangatlah penting, agar generasi penerus bangsa mempunyai moral yang baik. Generasi penerus mencerminkan kualitas bangsa. Apabila generasi penerusnya baik dalam kognitif dan moral maka baik pula suatu bangsa tersebut. Untuk itu keluarga, sekolah dan masyarakat mempunyai tanggung jawab untuk menciptakan generasi yang bermoral dan berakhlak baik.

\section{Peran Keluarga, Guru dan Masyarakat dalam Pendidikan Karakter}

\section{a. Peran Keluarga dalam Pendidikan Karakter}

Orang tua dapat terlibat dalam kegiatan pembudayaan dan penanaman karakter melalui beberapa kegiatan. Orang tua secara aktif dapat memantau perkembangan perilaku anak mereka melalui buku kegiatan siswa yang sudah disiapkan pihak sekolah. Orang tua secara aktif mengikuti kegiatan rutin atau bergilir yang dilaksanakan pihak sekolah dalam pertemuan-pertemuan antara orang tua dengan wali kelas dan guru-guru kelas.

Era Digital saat ini anak-anak usia sekolah dasar tidak bisa lepas dari gadget bahkan menjadi sebuah kebutuhan. Kondisi seperti itu, orang tua perlu memperkenalkan kepada anak-anak, situs pendidikan bila menggunakan gadget, seperti lagu-lagu islami dan pendidikan, games pendidikan yang mengasah kemampuan kognitif, video tata cara sholat, membersihkan kamar sendiri, dan lainnya, yang penting untuk diingat. Orang tua juga berperan mengawasi dan membatasi anak-anak dalam menggunakan ponsel, atur waktu kapan ia harus mengerjakan tugas sekolahnya, bersosialisasi dengan teman, bersosialisasi tengan keluarga, dan menggunakan ponsel atau gadget. 


\section{b. Peran Guru dalam Budaya Karakter di Sekolah}

Guru memepersiapkan berbagai pilihan dan strategi untuk menanamkan setiap nilai-nilai, norma-norma dan kebiasaan-kebiasaan ke dalam mata pelajaran yang diampunya. Guru dapat memilih cara-cara tertentu dalam proses pembelajarannya, seperti menyampaikan berbagai kutipan yang berupa kata-kata mutiara atau peribahasa yang berkaitan dengan karakter, cerita pendek, diskusi kelompok, membuat karangan pendek dan sebagainya. Setiap sekolah hendaknya menentukan kegiatan khusus yang dapat mengikat para guru untuk melakukan kegiatan tersebut secara berkelanjutan. Berikut contoh penerapan keteladan pendidikan karakter di sekolah:

a. Guru secara sadar datang pada jam 06.30 dan pulang jam 1.30, kehadiran guru yang demikian sebagai bentuk komitmen mereka terhadap budaya yang telah berlaku di sekolah yang bersangkutan.

b. Sekolah memberikan penghargaan terhadap setiap keberhasilan, usaha, dan memberikan komitmennya, semua karyawan dan siswanya akan termotivasi untuk bekerja keras, inovatif, dan mendukung perubahan.

c. Sekolah memberikan apresiasi pada saat upacara bendera pada hari senin, untuk guru, karyawan dan siswa yang berprestasi. Cara yang dilakukan ini memotivasi setiap guru, karyawan dan siswa untuk meraih prestasi-prestasi tertentu.

d. Sekolah menerapkan Kegiatan Gotong Royong setiap satu semester.

\section{c. Peran Masyarakat dalam Pendidikan Karakter}

Sekolah bersama komite sekolah dan masyarakat secara bersama-sama menyusun suatu kegiatan yang dapat mendukung terwujudnya pembudayaan dan penanaman karakter yang baik bagi seluruh warga sekolah kegiatan yang dapat dilakukan antara lain seperti, melakukan gotong royong membersihkan tempat-tempat umum seperti masjid, sungai, dan lainnya. Masyarakat juga memainkan peran tak kalah pentingnya sebagai contoh atau model yang dapat menjadi pendorong keberhasilan para siswa dalam menerapkan nilai norma, dan kebiasaan-kebiasaan karakter yang baik. Tokoh tokoh seperti pemangku adat dan ustadz bisa dihadirkan di sekolah untuk mengadakan kegiatan sharing atas kehidupan dan keberhasilan mereka. 


\section{SIMPULAN}

Karakter akan terbentuk bila aktivitas dilakukan berulang-ulang secara rutin hingga menjadi suatu kebiasaan, yang akhirnya tidak hanya menjadi suatu kebiasaan saja tetapi sudah menjadi suatu karakter. Pendidikan karakter dapat diterapkan pada semua mata pelajaran. Setiap mata pelajaran yang berkaitan denga norma-norma perlu dikembangkan dan dikaitkan dengan kehidupan sehari-hari.

Di era digital ini peran keluarga, guru dan masyarakat sekitar sangatlah penting dalam meningkatkan karakter calon penerus bangsa. Keluarga sebagai tempat utama dan pertama peserta didik menjalani kehidupan hendaklah mengawasi dan membimbing dengan penuh kasih sayang, tegas, dan cermat. Peran guru dalam membangun karakter peserta didik semakin meningkat, kompleks dan berat. Guru tidak hanya mengajarkan konsep karakter yang baik, tetapi bagaimana mengarahkan peserta didik untuk dapat mengimplementasikan pada kehidupam sehari-hari. Guru juga sebagai panutan harus menerapkan karakter yang baik pada dirinya sendiri. Masyarakat sekitar juga berperan dalam mengawasi dan memotivasi perkembangan karakter peserta didik.

\section{DAFTAR PUSTAKA}

Abeng Eddy Adriansyah Dkk. 2015. Jendela Keluarga. Bandung: MQS Publishing, Cet III.

Departemen Agama RI. 2000. Al-Qur'an dan Terjemahnya. Jakarta: PT. Intermasa. Departemen Pendidikan Nasional. 2003. Undang-Undang Republik Indonesia No. 20 Tahun 2003 Tentang Sistem Pendidikan Nasional. Jakarta: Depdiknas.

Daryanto, Darmiatun Suryatri. 2013. Implementasi Pendidikan Karakter di Sekolah. Yogyakarta: Gava Media.

Peraturan Menteri Pendidikan dan Kebudayaan Republik Indonesia Nomor 23 Tahun 2015. Jakarta: Permendikbud.

Peraturan Presiden No 87 Pasal 2 Tahun 2017, Penguatan Pendidikan Karakter, (http://www.setkab.go.id/wp-content/upload/2017/09/Perpres No 87 tahun 2017, (Diakses 20 april 2017)

Saiful Bahri. Implementasi Pendidikan Karakter dalam Mengatasi Krisis Moral di Sekolah , 2015, TA'ALLUM Vol 03. No 01, juni 2015 
50 | AR-RIAYAH : Jurnal Pendidikan Dasar vol. 2, no. 1, 2018

Salman Hasibuan. 2015. Budaya Media dan Partisipasi Anak di Era digital, Proceeding of International Post-Graduate Conference. Surabaya: Program Studi S2 dan Komunikasi Universitas Airlangga.

Sukiman, dkk. 2016. Seri Pendidikan Orang Tua: Mendidik Anak di Era Digital. Jakarta: Kementerian Pendidikan dan Kebudayaan.

Yulia Palupi, 2015. Digital Parenting Sebagai Wahana Terapi untuk Menyeimbangkan Dunia Digital dengan Dunia Nyata Bagi Anak, Yogyakarta: Seminar Nasional Universitas PGRI Yogyakarta tahun 2015. 